\title{
Aqueous wheat extract (Triticuma estivum) prevents carboplatin-induced myelosuppression and oxidative stress in Wistar rats
}

\section{Gustavo Soares Forlani ${ }^{1 *}$ Samuel Rodrigues Félix ${ }^{2} \odot$ Luciele Varaschini Teixeira $^{3} \odot$ Laura Michelon $^{1}$ Rodrigo Franco Bastos ${ }^{1} \odot$ Carmen Lúcia Garcez Ribeiro ${ }^{1} \odot$ Rogério Antônio Freitag $^{4} \odot$ Anelize de Oliveira Campello Félix ${ }^{1} \odot$ Márcia de Oliveira Nobre $^{1}[$}

${ }^{1}$ Departamento de Clínicas Veterinárias, Universidade Federal de Pelotas (UFPel), 96160-000, Campus Capão do Leão, RS, Brasil. E-mail: gustavo.forlani@hotmail.com. "Corresponding author.

${ }^{2}$ Instituto Federal de Educação, Ciência e Tecnologia Sul-rio-grandense (IFSul), Bagé, RS, Brasil.

${ }^{3}$ Departamento de Bioquímica, Universidade Federal do Rio Grande do Sul (UFRGS), Porto Alegre, RS, Brasil.

${ }^{4}$ Departamento de Ciências Químicas, Farmacêuticas e de Alimentos, Universidade Federal de Pelotas (UFPel), Pelotas, RS, Brasil.

ABSTRACT: The present study aimed to evaluate the use of aqueous wheat extracts as an adjunct to antineoplastic therapy with carboplatin. In this study, 32 rats were used which were randomly distributed into 4 groups: G1 - negative control; G2 - control treated with physiological solution; G3 - animals treated with aqueous extract of wheat in the concentration of 100mg/kg; G4 - animals treated with aqueous wheat extract at the concentration of $400 \mathrm{mg} / \mathrm{kg} ; 300 \mathrm{mg} / \mathrm{m}^{2}$ of carboplatin was administered intraperitoneally at day 0 in animals from groups $\mathrm{G} 2$, G3, and G4, whereas $1 \mathrm{ml}$ of physiological solution was administered by the same route in animals from group G1. Animals were treated daily for 21 days by orogastric gavage according to their respective experimental group. Blood was collected from animals on days 3, 7 and 21 for complete blood count (CBC), biochemistry, and measurement of paraoxonase 1 (PON1) activity. On day 21, animals were euthanized and necropsied. Promising results were obtained regarding oxidative balance in groups G3 and G4. Both presented better PONI activity in comparison with group G2 $(P<0.05)$. Total leukocyte count of group G4 differed significantly from group G2 $(P<0.05)$ on day 21 . Myelogram values of animals from groups $G 3$ and $G 4$ were similar to those from $G 1$; animals from $G 3$ had lower numbers of promyelocytes and increased numbers of erythrocytes and rubriblasts than animals from $G 2(P<0.05)$. In the present experimental study, aqueous wheat extract was safe at the doses used in the animals, and was an effective treatment for myelosuppression and for the prevention of an excessive release of free radicals induced by carboplatin.

Key words: chemotherapy, phytochemical, paraoxanase1, myelogram.

Extrato aquoso de trigo (Triticum aestivum) na prevenção da mielossupressão e estresse oxidativo induzidos pela carboplatina em ratos Wistar

RESUMO: O presente estudo avaliou a utilização dos extratos aquosos de trigo como adjuvante a terapia antineoplásica com carboplatina. No estudo foram utilizadas 32 ratas, as quais foram aleatoriamente distribuidas em quatro grupos: G1 - controle negativo; G2 - controle tratado com solução fisiológica; G3 - tratado com extrato aquoso de trigo na concentração de 100mg/kg; G4 - tratado com extrato aquoso de trigo na concentração de 400mg/kg. Administrou-se $300 \mathrm{mg} / \mathrm{m}^{2}$ de carboplatina por via intraperitoneal no dia 0 nos grupos G2, G3, e G4, enquanto no G1 foi administrado $1 \mathrm{~mL}$ de solução fisiológica pela mesma via. Os animais foram tratados diariamente durante 21 dias por gavagem orogástrica de acordo com seu respectivo grupo experimental. Foi coletado sangue dos animais nos dias três, sete e 21, para realização de hemograma, testes bioquimicos e mensuração da atividade da paraoxanase 1 (PON1). No dia 21 os animais foram eutanasiados e realizada coleta de medula óssea, rim e figado. Foram observados resultados promissores com relação ao balanço oxidativo no G3 e G4, pois ambos apresentaram melhor atividade da PON1 em relação ao G2 $(P<0,05)$. Além disso, foi constatado que os mesmos grupos apresentaram contagem de leucócitos totais superiores ao G2 durante todo o periodo experimental, com $G 4$ diferindo significativamente do $G 2(P<0,05)$ no dia 21. Os mielogramas dos animais do G3 e G4 apresentaram valores análogos ao G1, sendo que o G3 apresentou menor contagem de promielócitos e maior de células eritroides e rubroblastos que o $G 2(P<0,05)$. Nas condições experimentais deste estudo os extratos aquosos de trigo mostraram-se seguros nas doses utilizadas e úteis no tratamento da mielossupressão e liberação excessiva de radicais livres induzidas pelo fármaco carboplatina.

Palavras-chave: quimioterapia, phytochemical, paraoxanase 1, mielograma.

\section{INTRODUCTION}

Malignant neoplasms are among the most important diseases in humans and animals. Despite the large sums of money that have been invested over the years in research and therapeutic modalities, in 2012,
14.1 million new cases of cancer were diagnosed and 8.2 million human deaths due to cancer were recorded worldwide (FERLAY et al., 2015). To date, there is no global study in veterinary medicine on the occurrence and prevalence rate of cancer in animals, the American Association of Veterinary Practitioners estimates that 
of the 74 million dogs and 90 million cats in the US, at least 4 million of each species develop some type of neoplasia yearly (WITHROW, 2007).

The methods most often used in the treatment of neoplasms are surgical excision, radiotherapy, electrochemotherapy, and conventional and metronomic chemotherapy. Conventional chemotherapy is the method most widely used for the treatment of hematopoietic neoplasms, neoplastic masses which resection is not a viable option, and for the prevention of recurrence or metastases in cases in which surgical removal of the tumor is not feasible (BILLER, 2014; CASSALI et al., 2014).

$$
\text { Carboplatin [cis-diamine }
$$

(1,1-cyclobutanedicarboxyl) platin II] is an antineoplastic drug of the platinum group indicated for the treatment of mammary neoplasms, epithelial tumors, and other types of carcinoma. It has been extensively used since it is highly effective in the treatment ofneoplasms and lowersideeffects compared with other chemotherapy medications. Even though carboplatin is less toxic than other antineoplastic drugs, it still has severe adverse effects including myelosuppression and the marked release of free radicals (HUSAIN et al., 2001; WHEATE et al., 2010).

In order to balance the proportion of these free radicals, the body has a number of antioxidant mechanisms among which paraoxonase 1 (PON1) stands out. The PON1 is an antioxidant enzyme produced by hepatocytes which function is to neutralize reactive oxygen species (EROS), thus reducing lipid peroxidation (FANG et al., 2012).Although, the body possesses antioxidant mechanisms, these are not always sufficient to stop excess free radical production, i.e. oxidative stress (OS). The OS plays a major role in cell aging and induce deleterious changes in several tissues thus leading to the onset of various diseases such as Alzheimer's disease, atherosclerosis, and cancer (BARBOSA et al., 2010; KLAUNING et al., 2010; FANG et al. , 2012). Phytotherapy may be used to attenuate of the undesirable side effects of chemotherapy. Triticum aestivum stands out among the phytotherapic substances due to its composition which is rich in phenolic compounds and flavonoids. These compounds have a beneficial effect against hematopoietic (KHAN et al., 2015) and neoplastic disorders (DAS et al., 2015; Ki et al., 2017), help in the healing process (TILLMANN et al., 2014) (FERNANDES, et al., 2017), and have antioxidant properties (MOHAN et al., 2013).

The present study aimed to assess the myeloprotective and antioxidant properties of the wheat aqueous extract in healthy Wistar rats in rats submitted to the carboplatin drug at a dose of $300 \mathrm{mg} / \mathrm{m}^{2}$ intraperitoneally.

\section{MATERIALS AND METHODS}

\section{Preparation of T. aestivum aqueousextracts}

One kilo and five hundred grams of wheat was collected in the rural area of the municipality of Jaguarão in the state of Rio Grande do Sul (RS), south Brazil (32 33' $58^{\prime \prime}$ ' S, 53 22'33 ' L, altitude $26 \mathrm{~m}$ ). First, wheat a sample were desiccated, and exsiccates were submitted to the Federal University of Pelotas Herbarium (UFPel, RS, Brazil) for identification and cataloging (PEL 24,600). Subsequently, the remaining material (peduncle with ear and seeds) was dried, ground, and sent to the Laboratory of Olechemistry and Biodiesel of the Center of Chemical, Pharmaceutical and Food Sciences of UFPel for extraction of products using the ultrasonic technique by exhaustion. Immediately, after obtaining the extracts, these samples were subjected to freezing in a ultrafreezer $\left(-86^{\circ} \mathrm{C}\right)$, and after 24 hours these specimens were lyophilized, quantified, and separated into aliquots for daily use. A sample of the final product was sent for high performance liquid chromatography (HPLC) according to the methodology described by TILMANN et al. $(27 \mathrm{mg} / \mathrm{g})$. Major components included apigenin $(37 \mathrm{mg} / \mathrm{g})$, caempferol $(172 \mathrm{mg} / \mathrm{g})$, and quercetin $(78 \mathrm{mg} / \mathrm{g})$.

\section{Animals and experimental protocols}

The experiment was approved by the Ethics Committee on Animal Experimentation of UFPel (CEEA-10447). Thirty-two 80 day-old female Wistar rats with an average weight of $212 \mathrm{~g}$ originated from the UFPel Central Animal Hospital were included in this study. Animals were kept under recommended conditions; with the environmental temperature controlled $\left(21^{\circ} \mathrm{C} \pm 2^{\circ} \mathrm{C}\right)$, and daily cycle maintenance with 12 hours light and 12 hours of dark. These animals were provided with Nuvilab cr $1{ }^{\circledR}$ feed and filtered water ad libitum. After a 15 day adaptation period, these animals were randomly assigned to 4 groups and subsequently received a single intraperitoneal dose of carboplatin or $0.9 \%$ saline as described in Table 1 . The doses of the aqueous extracts of wheat were calculated based on those from previous studies in the murine model in which the antioxidant (MOHAN et al., 2013) and immunoprophylactic properties (KHAN et al., 2015) of an ethanolic extract of wheat were evaluated. However, the doses of $300 \mathrm{mg} / \mathrm{m}^{2}$ of the antineoplastic 
Table 1 - Protocol of induction with carboplatin and treatment in the different experimental groups.

\begin{tabular}{lcc}
\hline Group & Induction of effects of therapy on day 0 & Daily treatment in 21 days \\
G1 & NaCl $0,9 \%$ & $\mathrm{NaCl} 0,9 \%$ \\
G2 & Carboplatin $300 \mathrm{mg} / \mathrm{m}^{2}$ & $\mathrm{NaCl} 0,9 \%$ \\
G3 & Carboplatin $300 \mathrm{mg} / \mathrm{m}^{2}$ & A.E. T. aestivum $100 \mathrm{mg} / \mathrm{kg}$ \\
G4 & Carboplatin $300 \mathrm{mg} / \mathrm{m}^{2}$ & A.E. T. aestivum $100 \mathrm{mg} / \mathrm{kg}$ \\
\hline
\end{tabular}

drug carboplatin was chosen based on previous research on the use of this drug in the treatment of sarcomas and carcinomas in dogs (CASSALI et al., 2014, VIANA, F. 2014).

Animals were treated daily for 21 days by orogastric gavage $(0.5 \mathrm{~mL})$ according to their respective experimental group. On days 3 and 7, blood samples were collected from the retrobulbar plexus with the aid of anesthetic eye drops and Pasteur type pipettes. On day 21, blood was collected from the heart (cardiac puncture) under general anesthesia. At the end of the 21 days of treatment, all animals were the euthanasied with anesthetic overdose of following the recommendations of the Council on the Ethics of Animal Experimentation. After euthanasia, the cranial epiphysis of the right femur from each animal was bevel sectioned, bone marrow samples were collected by aspiration, and smears were prepared. These smears were stained by the rapid panoptic method. Samples of the right kidney and liver were fixed in $10 \%$ formalin and submitted to the Regional Diagnostic Laboratory of the School of Veterinary Medicine at UFPel. Samples were routinely processed for histology and included in paraffin; $5 \mu \mathrm{m}$ sections were prepared and stained with Hematoxylin and Eosin (H\&E).

\section{Parameters analyzed}

Hemogram were performed on days 3, 7, and 21 using the PocH-100iV Diff ${ }^{\text {}}$ hematological analyzer. The following parameters were evaluated: erythrocyte count (RBC), hemoglobin, hematocrit, mean corpuscular volume (MCV), corpuscular hemoglobin concentration (CHCM), total and differential counts of leukocytes (neutrophils, lymphocytes, monocytes, and eosinophils), and platelets. For the biochemical analyses, serum samples were obtained by centrifuging blood specimens stored in microtubes at 3500rpm for 5 minutes. Standardized diagnostic kits $\left(\right.$ Labtest $^{\mathbb{R}}$ ) were used for spectrophotometry of alkaline phosphatase (ALF), alanine aminotransferase (ALT), urea, and creatinine using a semi-automatic analyzer for clinical chemistry (Mindray BA- $88^{\circledR}$ ).
Bone marrow samples collected for smear preparation were also used for the myelograms. Smears were stained with rapid panopticus and analyzed under an optical microscope (Olympus CX31). Megakaryocytes count was performed under 10x magnification whereas the other cell counts (rubriblite, prokaryotic, rubrícito, metarrubic, myeloblast, promyelocyte, metamielocyte, myelocyte, rodent, eosinophils, basophils, neutrophil, lymphocyte, plasma cell, and monocyte counts) were done using the $100 \mathrm{x}$ objective with oil immersion. In each smear, 500 cells were evaluated. Cell diameter and morphology of the nucleus and cytoplasm were assessed (HARVEY, 2001; CASTRO et al., 2011).

Toxicity of platinates were determined by measuring PON1 activity 72 hours after an injection of carboplatin (day 3) (SUEISHI et al., 2002; SANTOS et al., 2007). The phenylacetate technique (SigmaAldrich) was used to measure the activity of this enzyme. In this method, phenol formation was determined and captured by absorbance reading at $270 \mathrm{~nm}$ and $25^{\circ} \mathrm{C}$ according to the manufacturer's specifications. The working reagent used was composed of $100 \mathrm{ml}$ of $20 \mathrm{~mm}$ Tris/ $\mathrm{HCl} \mathrm{pH} 8.0$ buffer containing $1 \mathrm{~mm}$ of $\mathrm{CaCl} 2$ and $50 \mathrm{ul}$ of phenylacetate as substrate. Samples were diluted 1 to 3 in buffer, and 3.3ul of this dilution was added in 500ul of the working solution. Reading was performed on a spectrophotometer using a quartz cuvette within the range of $270 \mathrm{~nm}$ with 20 seconds of retention and 1 minute for reading (FELIX, 2014).

Kidney and liver tissue samples were included in paraffin; $5 \mu \mathrm{m}$ histological sections were prepared and evaluated under the light microscope (400x magnification). The presence or absence of inflammatory, proliferative, and degenerative lesions were investigated in the histological sections of these two organs.

\section{Statistical analysis}

Data were submitted to analysis of variance (ANOVA) with the Tukey test using the Graphpad 
Prism $5^{\circledR}$ software. Differences between groups were considered significant if $\mathrm{P}<0.05$.

\section{RESULTS}

\section{Blood count}

Haematological parameters remained stable throughout the experiment in animals from G1. In animals from the experimental groups G3 and G4 which were treated with aqueous wheat extract, increased total leukocyte and erythrocyte counts were observed when compared to those animals from group G2, and was significantly higher in the day $21(\mathrm{P}<0.05)$. Significant thrombocytopenia was observed in all carboplatin-treated groups. The other haematological parameters are shown in Table 2.

\section{Myelogram}

Myelograms of animals from G2 showed a significant decrease in the total number of rubriblasts and promyelocytes when compared to animals from G1 $(\mathrm{P}<0.05)$. Myelogram counts of animals from groups G3 and G4 which were treated with aqueous wheat extract were similar to those from controls in the majority of the haematological parameters assessed (Table 3). However, animals from group G3 had lower numbers of promyelocytes compared with those from group $\mathrm{G} 2$, and numbers were similar to those from group G1. All the data regarding the myelograms of these animals are presented in table 3 .

\section{PON1 activity}

Animals of the groups treated with aqueous wheat extract (G3 and G4) showed higher activity of the

Table 2 - Mean values of hemograms from rats treated with aqueous wheat extract (groups G3 and G4) after induction with carboplatin compared with control groups (groups G1 and G2).

\begin{tabular}{|c|c|c|c|c|c|c|c|c|}
\hline & & & Leuko $(\mu \mathrm{L})$ & Eosi $(\mu \mathrm{L})$ & Mon $(\mu \mathrm{L})$ & Lympho $(\mu \mathrm{L})$ & Bands $(\mu \mathrm{L})$ & Seg $(\mu \mathrm{L})$ \\
\hline \multirow{12}{*}{ Leucometry } & \multirow{4}{*}{ Day 3} & G1 & $5487.5^{\mathrm{a}}$ & 12.3 & 27.8 & $4798.2^{\mathrm{a}}$ & 0.0 & $649.0^{\mathrm{a}}$ \\
\hline & & G2 & 3737.5 & 11.8 & 54.8 & 2656.6 & 0.0 & 289.5 \\
\hline & & G3 & 4725.0 & 12.6 & 52.3 & $4049.8^{\mathrm{a}}$ & 0.0 & 610.1 \\
\hline & & G4 & 4750.0 & 10.0 & 74.1 & $4180.8^{\mathrm{a}}$ & 0.0 & 485.0 \\
\hline & \multirow{4}{*}{ Day 7} & G1 & 5137.5 & $53.2^{\mathrm{a}}$ & 34.3 & 3609.3 & 0.0 & 1328.0 \\
\hline & & G2 & 4375.0 & 6.0 & 5.6 & 3797.1 & 0.0 & 566.2 \\
\hline & & G3 & 4575.0 & 35.6 & 26.5 & 3703.6 & 0.0 & 809.1 \\
\hline & & G4 & 4483.3 & 34.5 & 23.8 & 3359.5 & 0.0 & $1065.5^{\mathrm{a}}$ \\
\hline & \multirow{4}{*}{$\begin{array}{c}\text { Day } \\
21\end{array}$} & G1 & 5350.0 & 44.2 & 35.1 & 4645.2 & 0.0 & 625.3 \\
\hline & & G2 & 4262.5 & 46.6 & 33.0 & 3663.8 & 0.0 & 894.0 \\
\hline & & G3 & 5328.5 & 48.5 & 25.2 & 4109.7 & 0.0 & 1145.0 \\
\hline & & G4 & $6420.0^{\mathrm{a}}$ & 80.1 & 22.3 & $5409.0^{\mathrm{a}}$ & 0.0 & 1188.6 \\
\hline \multirow{13}{*}{ Red blood cell count } & & & PCV (\%) & Erithrocyte $\times 10^{6} / \mu \mathrm{L}$ & $\mathrm{Hb}(\mathrm{g} / \mathrm{dL})$ & Platelets $(\mathrm{mil} / \mu \mathrm{L})$ & VCM (fL) & CHCM (\%) \\
\hline & \multirow{4}{*}{ Day 3} & G1 & 47.6 & 8.6 & 16.0 & 1010.0 & 55.19 & 33.7 \\
\hline & & G2 & 46.4 & 8.3 & 15.4 & 987.2 & 54.61 & 33.8 \\
\hline & & G3 & 48.2 & 8.6 & 16.0 & 982.8 & 55.66 & $33.3^{\mathrm{a}}$ \\
\hline & & G4 & 46.5 & 8.4 & 36.6 & 1047.3 & 54.83 & $33.0^{\mathrm{a}}$ \\
\hline & \multirow{4}{*}{ Day7 } & G1 & 46.6 & $8.4^{\mathrm{a}}$ & $15.7^{\mathrm{a}}$ & $1053.8^{\mathrm{a}}$ & 55.54 & 33.7 \\
\hline & & G2 & 43.4 & 7.6 & 14.5 & 649.2 & 56.35 & 33.7 \\
\hline & & G3 & 43.7 & 7.8 & 14.7 & 667.7 & 55.94 & 33.7 \\
\hline & & G4 & 43.0 & 7.8 & 14.4 & 566.6 & 54.70 & 33.6 \\
\hline & \multirow{4}{*}{ Day21 } & G1 & 45.6 & $8.2^{\mathrm{a}}$ & 15.4 & 944.6 & 55.36 & 33.8 \\
\hline & & G2 & 44.4 & 7.8 & 14.9 & 1000.1 & 56.84 & 33.6 \\
\hline & & G3 & 46.1 & 8.1 & 15.4 & 927.2 & 56.76 & 33.5 \\
\hline & & G4 & 45.0 & 8.0 & 15.1 & 1100.3 & 56.15 & 33.6 \\
\hline
\end{tabular}

Treatments: G1 - Saline 0.9\%, without injection of carboplatin; G2 - Saline 0.9\%, with injection of carboplatin; G3 - T. aestivum 100mg.Kg-1, with injection of carboplatin; G4 - T. aestivum 400mg.Kg-1, with injection of carboplatin. ${ }^{\mathrm{a}} \mathrm{Represents} \mathrm{a} \mathrm{statistically}$ different value from the group induced and treated with saline $0.9 \%(\mathrm{G} 2) \mathrm{P}<0.05)$ Leuc. - Total leukocytes; Eosi - Eosinophils; Mon Monocytes;Lympho - Lymphocytes; Ban - Bands;Seg - Segmented; PCV - Hematocrit;Eryt - Erythrocytes; Hb - Hemoglobin; VCM Mean Corpuscular Volume;CHCM - Mean Corpuscular Hemoglobin Concentration. 
Table 3 - Myelogram (mean) of rats without induction (G1), induction without treatment (G2), induction and treated with aqueous extract of T. aestivum (G3 and G4) on day 21 after administration of a single dose of carboplatin intraperitoneally.

\begin{tabular}{|c|c|c|c|c|}
\hline & G1 & $\mathrm{G} 2$ & G3 & G4 \\
\hline & \multicolumn{4}{|c|}{------------------------------------------Granulocytic series----------------------------------------- } \\
\hline Total number of cells (/500 cells) & 224.86 & 287.75 & 240.14 & 246.33 \\
\hline Promyelocytes $(\%)$ & $1.29^{\mathrm{a}}$ & $2.85^{\mathrm{b}}$ & $0.97^{\mathrm{a}}$ & $1.7^{\mathrm{ab}}$ \\
\hline Myelocytes (\%) & 9.57 & 9.25 & 8.54 & 7.87 \\
\hline Metamyelocytes (\%) & 7.34 & 6.85 & 7.79 & 7.43 \\
\hline Bands $(\%)$ & 10.29 & 9.9 & 10.6 & 9.67 \\
\hline Segmented (\%) & $14.77^{\mathrm{b}}$ & $26.6^{\mathrm{a}}$ & $18.31^{\mathrm{ab}}$ & $18.62^{\mathrm{ab}}$ \\
\hline Eosinophils (\%) & 1 & 1.25 & 1.23 & 2.33 \\
\hline Basophils (\%) & $0.14^{\mathrm{b}}$ & $0.2^{\mathrm{ab}}$ & $0.11^{\mathrm{b}}$ & $0.5^{\mathrm{a}}$ \\
\hline Monocytes (\%) & 0.37 & 0.6 & 0.36 & 0.37 \\
\hline Lymphocytes (\%) & 6.3 & 6.28 & 4.33 & 4.92 \\
\hline Plasma cells (\%) & 0.33 & 0.18 & 0.1 & 0.45 \\
\hline \multirow[t]{2}{*}{ Megakaryocytes (/10x field) } & $5-10$ & $2-10$ & $0-10$ & $0-6$ \\
\hline & \multicolumn{4}{|c|}{ 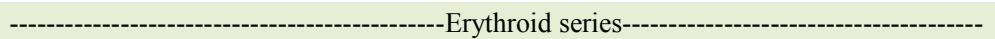 } \\
\hline Total number of cells (/500 cells) & $240.43^{\mathrm{a}}$ & $177^{\mathrm{b}}$ & $236^{\mathrm{ab}}$ & $235.17^{\mathrm{ab}}$ \\
\hline Rubriblasts (\%) & $0.54^{\mathrm{ab}}$ & $0.75^{\mathrm{b}}$ & $0.36^{\mathrm{ab}}$ & $1.1^{\mathrm{a}}$ \\
\hline Prorubricytes $(\%)$ & 2.03 & 3.4 & 1.76 & 3.2 \\
\hline Rubricytes (\%) & 10.6 & 8.05 & 10.06 & 13.5 \\
\hline \multirow[t]{3}{*}{ Metarubricytes (\%) } & 34.89 & 23.2 & 35.03 & 27.72 \\
\hline & \multicolumn{4}{|c|}{-----------------------------'Granulocytic series/Erythroid series ratio---------------------- } \\
\hline & $0.98^{\mathrm{b}}$ & $1.73^{\mathrm{a}}$ & $1.07^{\mathrm{ab}}$ & $1.08^{\mathrm{ab}}$ \\
\hline
\end{tabular}

Treatment: G1-Saline 0.9\%; G2 - Saline 0.9\% + carboplatin; G3 - T. aestivum $100 \mathrm{mg} / \mathrm{kg}+$ carboplatin; G4 - T. aestivum 400mg/kg + carboplatin

${ }^{\mathrm{ab}}$ Different letters represent statistically different values in the row $(\mathrm{P}<0.05)$.

PON1 enzyme, being statistically equivalent to group $\mathrm{G} 1$ and higher than group G2 $(\mathrm{P}<0.05)$ (Figure 1).

\section{Serum biochemistry and histopathology}

Biochemical analyses including AF, ALT, urea, and creatinine did not differ between groups, and remained within the physiological parameters for the species throughout the experimental trial. Similarly, no significant microscopic changes were observed by histopathology which is consistent with animals from group G1 as these animals did not received an injection of carboplatin and were not treated with wheat aqueous extracts.

\section{DISCUSSION}

To the authors' knowledge, this is the first study to show that wheat aqueous extract may be used as an adjuvant in chemotherapy, and is capable of reducing the side effects of myelosuppression and oxidative stress which are the adverse effects most frequently observed in the treatment of cancer with carboplatin (HUSAIN et al., 2001; WHEATE et al. 2010). Inhibition of the decrease in PON1 activity is related to the neutralization of free radicals which was observed in both groups treated with wheat extract $(100 \mathrm{mg} / \mathrm{kg}$ and $400 \mathrm{mg} / \mathrm{kg})$. The maintenance of the physiological activity suggested that this extract has an antioxidant action possibly because it is rich in phenolic compounds (p-coumarinic acid, carnosic acid, apigenin, and quercetin) and flavonoids (caempferol acid). Other authors have shown in previous studies that the aforementioned compounds are antioxidants (SHAN et al., 2005; WOJDYLO et al., 2007; MASUOKA et al., 2012). The antioxidant effect of wheat has also been reported in vitro (DAS et al., 2015) and in vivo (MOHAN et al., 2013). However, its ability to increase PON1 activity of is a novel finding.

The myeloprotective action of the wheat extract was demonstrated by the results of the blood count. Hemograms showed that animals from groups 


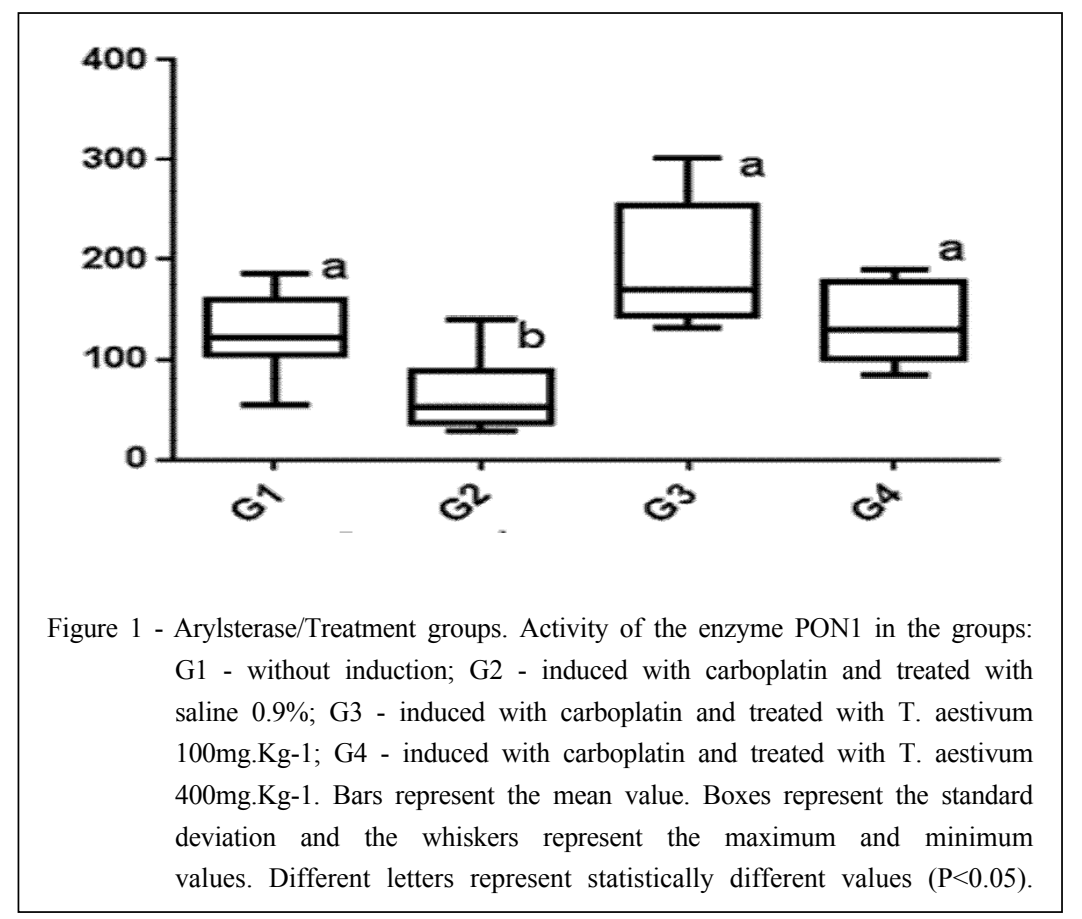

G3 and G4 had higher leukometry than animals from G2 throughout the entire experimental trial. On day 21, leucometry was significantly higher in group G4 than in the other groups $(\mathrm{P}<0.05)$. In addition, myelograms showed that animals from G4 had total numbers of erythroid precursors, promyelocytes, and segmented neutrophils close to the values of those animals which were not subjected to carboplatin. In contrast, animals from $\mathrm{G} 2$ had values significantly lower than those from $\mathrm{G} 1(\mathrm{P}<0.05)$. These results corroborated the potential of aqueous wheat extract as an adjuvant in antineoplastic therapy since its myeloprotective action is extremely beneficial to cancer patients. A decrease in the total number of leukocytes and their precursors may result in serious complications due to immunosuppression, thus compromising the completion of the antineoplastic treatment and causing secondary opportunistic infections that may be fatal in these patients (HAHNAST, et al., 2010, WUKETICH, et al., 2012). However, it is important to emphasize that changes in the myelogram are not always accompanied by changes in the hemogram (ALMEIDA, et al., 2009). Therefore, it is fundamental that both tests are interpreted together. In this study, there was improvement in both myelogram and leukogram parameters. These findings show the myeloprotective effect of wheat extract.

The favorable response to the oxidative balance at the dose of $100 \mathrm{mg} / \mathrm{kg}$ was demonstrated by MOHAN et al. (2013). However, in this previous study, an ethanolic extract was used which differs from our study in which promising results were obtained using an aqueous extract. The same may be inferred with respect to the antileukopenic effect of the extract, which was shown by KHAN et al. (2015). The authors demonstrated that wheat ethanolic extracts at a dose of $400 \mathrm{mg} / \mathrm{kg}$ were beneficial for myelosuppressed animals, increasing the total number of leukocytes and promoting chemotaxis of neutrophils during interaction with pathogens. Thus, our results demonstrated that the wheat aqueous extracts at concentrations of 100 and $400 \mathrm{mg} / \mathrm{kg}$ are as efficient as ethanol. This result suggested that extraction with a non-toxic solvent (water) preserves the therapeutic properties of the extract, especially the phenolic compounds, since they were reported as responsible for the therapeutic effects in the aforementioned studies previously published by other authors elsewhere.

Although, this study has been carried out in healthy rats, its positive results in the oxidative and hematopoietic balance may be particularly important in patients undergoing chemotherapy with platinum. A murine model study with experimentally induced melanoma demonstrated that wheat extract had an antineoplastic effect which is similar to cisplatin (KI et al., 2017). This finding showed that the extract may be useful both as supportive therapy for its antioxidant effect (MOHAN et al., 2013; DAS et al., 2015) and as 
an immuno stimulant (KHAN et al., 2015), and also directly induces apoptosis of neoplastic cells (DAS et al., 2015, KI et al., 2017).

\section{CONCLUSION}

We concluded that aqueous wheat extract at a dose of $100 \mathrm{mg} / \mathrm{kg}$ and $400 \mathrm{mg} / \mathrm{kg}$ are effective in reducing the myelosuppressive effect andoxidative stress caused by carboplatin.

\section{ACKNOWLEDGMENTS}

We thank CAPES and CNPq (grant 305072/2012 9) for research funding. We also thank Labtest ${ }^{\circledR}$ company for providing the biochemistry test kits. We thank the Nutrition Laboratory of the Federal University of Pelotas-UFPel, RS, Brazil, for providing infrastructure and technical support for this study, and the Laboratory Animal Central Unit of UFPel for the structure and support of its team.

\section{COMMITTEE ON ETHICS AND BIOSAFETY}

CEEA permit 23110.010447/2014-59.

\section{DECLARATION OF CONFLICTING OF INTERESTS}

The authors declare no conflict of interest. The founding sponsors had no role in the design of the study; in the collection, analyses, or interpretation of data; in the writing of the manuscript, and in the decision to publish the results.

\section{AUTHORS' CONTRIBUTIONS}

Gustavo Forlani, Samuel Félix, Anelize Félix and Márcia Nobre were the main authors, the others authors contributed equally to the manuscript

\section{REFERENCES}

ALMEIDA, R. K. et al. Cytological alterations of the bone marrow and peripheral blood of dogs with canine distemper. Arquivo Brasileiro de Medicina Veterinária e Zootecnia, Belo Horizonte, v.61, n.6, p.1255-1260, 2009. Available from: <http://www.scielo. br/scielo.php?script=sci_arttext\&pid=S0102-09352009000600001> Accessed: Aug. 18, 2018. doi: 10.1590/S0102-09352009000600001.

BARBOSA, K. B. F et al. Oxidative stress: concept, implications and modulating factors. Revista de Nutrição, v.23, n.4, p.629-643, 2010. Available from: $<$ http://www.scielo.br/scielo.php?script $=$ sci arttext\&pid=S1415-52732010000400013 >. Accessed: Aug. 18, 2018. doi: 10.1590/S1415-52732010000400013.

BILLER, B. Metronomic chemotherapy in veterinary patients with cancer. The Veterinary Clinics of North America Small Animal Practice, v.44, n.5, p.817-829, 2014. Available from: <https:// www.ncbi.nlm.nih.gov/pubmed/25174901>. Accessed: Aug. 18, 2018. doi: 10.1016/j.cvsm.2014.05.003.

CASSALI, G. D. et al. Consensus for the diagnosis, prognosis and treatment of canine mammary tumors. Brazilian Journal of Veterinary Pathology, Jaboticabal, v.7, n.2, p.38-69, 2014. Available from: <http://bjvp.org.br/wp-content/uploads/2015/07/ DOWLOAD-FULL-ARTICLE-1-20881_2014_7_31_6_23.pdf $>$. Accessed: Aug. 18, 2018.

CASTRO, R. D. et al. Bone marrow examination in rats with thyroid dysfunction. Arquivo Brasileiro de Medicina Veterinária e Zootecnia, Belo Horizonte, v.63, n.5, p.1246-1250, 2011. Available from: $\quad<\mathrm{http}$ :/www.scielo.br/scielo.php?script $=$ sci abstract\&pid=S0102-09352011000500030\&lng=pt\&nrm=iso $>$. Accessed: Aug. 18, 2018. doi: 10.1590/S0102-09352011000500030.

DAS, P. et al. Antioxidative and anti carcinogenic activities of methyl pheophorbide a, isolated from wheat grass (Triticum aestivum Linn.). Natural Product Research: Formerly Natural Product Letters, v.18, n.1-4, p.474-477, 2015. Available from: $<$ https://www.ncbi.nlm.nih.gov/pubmed/25782530>. Accessed: Aug. 18, 2018. doi: 10.1080/14786419.2015.1022775.

FANG, D. H. et al. Differential effects of para oxonase 1 (PON1) polymorphisms on cancer risk: evidence from 25 published studies. Molecular Biology Reproduction, Holanda, v.39, n.6, p.6801-6809, 2012. Available from: <https://www.ncbi.nlm.nih. gov/pubmed/22322559>. Accessed: Aug. 18, 2018. doi: 10.1007/ s11033-012-1505-3.

FERNANDES, C.P.M et al. A randomized, double-blind, placebocontrolled study to assess the effect of an aqueous extract of Triticum aestivum on canine outer ear inflammation. Pesquisa Veterinária Brasileira, v.37, n.11, p.1270-1274. 2017. Available from: <http:// www.scielo.br/scielo.php?script $=$ sci arttext\&pid $=$ S0100-736X20 17001101270\&lng=en\&tlng=en>. Accessed: Aug. 18, 2018. doi: $10.1590 / \mathrm{s} 0100-736 \times 2017001100012$.

FERLAY, J. et al. Cancer incidence and mortality worldwide: sources, methods and major patterns in GLOBOCAN 2012. International Journal of Cancer, Germany, v.136, n.5, p.E359-E386, 2015. Available from: <https://www.ncbi.nlm.nih.gov/pubmed/25220842>. Accessed: Aug. 18, 2018. doi: 10.1002/ijc.29210.

HAHN-AST, C. et al. Overall survival and fungal infection-related mortality in patients with invasive fungal infection and neutropenia after myelo supressive chemotherapy in a tertiary care center from 1995 to 2006. The Journal of Antimicrobial Chemotherapy, v.65, n.4, p.761-768, 2010. Available from: <https://www.ncbi. nlm.nih.gov/pubmed/20106864>. Accessed: Aug. 18, 2018. doi: 10.1093/jac/dkp507.

HARVEY, J. W. Veterinary Hematology: Blood and bone marrow of domestic animals. 1 Ed. p.224. 2001.

HUSAIN, K. et al. Carboplatin-induced oxidative stress in rat cochlea. Hearing research, v.159, n(1-2), p.14-22, 2001. Available from: <https://www.sciencedirect.com/science/article/ pii/S0378595501003069?via\%3Dihub>. Accessed: Aug. 18, 2018. doi: 10.1016/S0378-5955(01)00306-9.

$\mathrm{KI}$, H. et al. In vitro and in vivo anti-cancer activity of dichloromethane fraction of Triticum aestivum sprouts. Biomedicine \& Pharmacotherapy, v.96 p.120-128, 2017. Available from: $<$ https:// www.ncbi.nlm.nih.gov/pubmed/28972884>. Accessed: Aug. 18, 2018. doi: 10.1016/j.biopha.2017.09.118.

KHAN, N. et al. Immuno prophylatic potential of wheat grass extract on benzene induced leukemia: An in vivo study on murine model. 
Indian Journal of Pharmacology, India, v.47, n.4, p.394-397, 2015. Available from: <https://www.ncbi.nlm.nih.gov/pubmed/26288471>. Accessed: Aug. 18, 2018. doi: 10.4103/0253-7613.161261.

KLAUNING, J. E. et al. Oxidative stress and Oxidative Damage in Carcinogenesis. Toxicology Pathology, v.38, p.96-109, 2010. Available from: <https://www.ncbi.nlm.nih.gov/pubmed/20019356>. Accessed: Aug, 18. 2018. doi: 10.1177/0192623309356453.

MASUOKA, N.; et al. Characterization of the antioxidant activity of flavonoids. Food Chemistry, Barking, v.131, n.2, p.541-545, 2012. Available from: <https://www.tib.eu/en/search/ id/elsevier\%3Adoi 10.1016\%252Fj.foodchem.2011.09.020/ Characterisation-of-the-antioxidant-activity-of/?tx_tibsearch search $\% 5$ Bsearchspace $\% 5 \mathrm{D}=\mathrm{tn}>$. Accessed: Aug. 18, 2018. doi: 10.1016/j.foodchem.2011.09.020.

MOHAN, Y. et al. Antidiabetic and antioxidant properties of Triticum aestivum in streptozotocin-induced diabetic rats. Advances in Pharmacological Sciences, Cairo, Article ID716073, p.9, 2013. Available from: <https://www.ncbi.nlm.nih.gov/pmc/articles/ PMC3876669/>. Accessed:Aug. 18, 2018. doi: 10.1155/2013/716073.

SANTOS, N.A, et al. Dimethy lthiourea protects against mitochondrial oxidative damage induced by cisplatin in liver of rats. Chemico Biological Interactions, v. 170 n.3 p.170:177-186, 2007. Available from: <https://www.ncbi.nlm.nih.gov/pubmed/17850778>. Accessed: Aug. 18, 2018. doi: 10.1016/j.cbi.2007.07.014.

SHAN, B. et al. Antioxidant capacity of 26 spice extracts and characterization of their phenolic constituents. Journal of Agricultural and Food Chemistry, Easton, v.53, n.20, p.7749-7759, 2005. Available from: <https://www.ncbi.nlm.nih.gov/pubmed/16190627>. Accessed: Aug. 18, 2018. doi: 10.1021/jf051513y.

SUEISHI, K. et al. Protection by a radical scavenger edaravone against cisplatin-induced nephrotoxicity in rats. European
Journal of Pharmacology, v.451 n.2 p.203-208, 2002. Available from: <https://www.sciencedirect.com/science/ article/pii/S0014299902022513?via\%3Dihub>. Accessed: Aug. 18, 2018. doi: 0.1016/S0014-2999(02)02251-3.

TILLMANN, M.etal. Useof Triticumaestivum inopenwoundhealing: a clinical, pathological, and tension metric assessment in the rabbit model. Arquivo Brasileiro de Medicina Veterinária e Zootecnia, v.6,p.1757-1767,2014. Available from: <http://www.scielo.br/ scielo.php?script=sci_arttext\&pid=S0102-09352014000601757>. Accessed: Aug. 18, 2018. doi: 10.1590/1678-7132.

VIANA, F. A. B. Guia terapêutico veterinário. $3^{\circ}$ Edição., p. 88, 2014.

WHEATE, N. J. et al. The status of platinum anticancer drugs in the clinic and in clinical trials. Journal for Inorganic, Organometallic and Bioinorganic Chemistry, v.39, n.35, p.8113-8127, 2010. Available from: $<$ http://pubs.rsc.org/en/Content/ArticleLanding/2010/ DT/c0dt00292e\#!divAbstract $>$. Accessed: Aug. 18, 2018. doi: 10.1039/c0dt00292e.

WITHROW, S. J. Why Worry About Cancer in Pets? In: VAIL, D. M. WITHROW, S.J. Withrow and Macewen's small animal clinical oncology, 4 ed., p.15-17, 2007.

WOJDYLO, A. et al. Antioxidant activity and phenolic compounds in 32 selected herbs. Food Chemistry, Barking, v.105, n.3, p.940-949, 2007. Available from: <http://www.sciencedirect. com/science/article/pii/S0308814607003974>. Accessed: Aug. 18, 2018. doi: 10.1016/j.foodchem.2007.04.038.

WUKETICH, S. et al. Prevalence of clinically relevant oral mucositis in outpatients receiving myelosuppressive chemotherapy for solid tumors. Supportive Care in Cancer, Dinamarca, v. 20, n.1, p.175-183, 2012. Available from: $<$ https://www.ncbi.nlm.nih. gov/pubmed/21331484>. Accessed: Aug. 18, 2018. doi: 10.1007/ s00520-011-1107-y. 